DOI :10.31357/fapsmst.2006.00479

INCIDENCE OF COLIFORM, YEAST AND

MOULDS IN YOGHURT AND ITS RELATIONSHIP

TO SHORTENING OF SHELF LIFE

BY

BUDAGODA ARACHCHIGE DONA RASIKA SANDEEPANI WIJEWARDENA 


\title{
INCIDENSE OF COLIFORM, YEAST AND MOULDS IN YOGHURT AND ITS RELATIONSHIP TO SHORTENING OF SHELF LIFE
}

\author{
By \\ B.A.D.RASIKA SANDEEPANI WIJEWARDANA
}

Thesis submitted to the University of Sri Jayawardanapura for the award of degree of Master of Science in Food Science and Technology on July 2006 
The work described in this thesis was carried out by me under the supervision of Prof A .Bamunuarachchi and report on this has not been submitted in whole or in part to any University or any other institution for another Degree.

Date 29.11.2006.

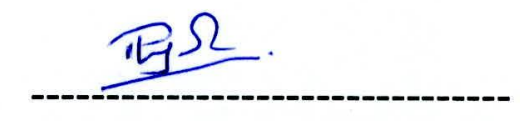

B.A.D.R.S Wijewardana 


\section{DECLARATION}

I / We certify that the above statement made by the candidate is true and that this thesis is suitable for submission to the university for the purpose of evaluation.

Prof A.Bamunuarachchi

(Internal Supervisor)

Department of Food Science and Technology

University of Sri Jayawardanapura

Sri Lanka

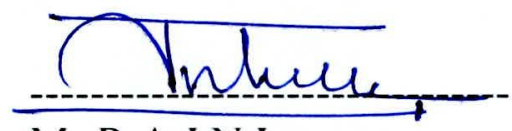

Mr R.A.J.N Luxman

(External Supervisor)

Manager, Q.A.R.D

Milco (Pvt) Limited

No 45, Nawala Road

Narahenpita

Sri Lanka 


\section{TABLE OF CONTENTS}

\section{Page}

Table of content

List of Tables

List of Figures

List of Abrevations

V111

Acknowledgement

\section{Abstract}

$\mathbf{X}$

1. INTRODUCTION

2. LITERATURE REVIEW

2.1 Milk

2.2 Chemical properties of Milk

2.2.1 Milk Lipids

2.2.2 Milk

2.2.3 Vitamins

2.2.4. Minerals

07

2.2.5 Enzymes

09

2.2.6 Lactose

09

2.3 Food and nutritive value of milk

10

2.4 Fermented dairy products

2.4.1Yoghurt

2.4.2 Yoghurt Starter culture 12

2.4.3 Manufacturing Method 12

2.4.4 Other Yogurt Products 15 
2.6 Yoghurt and health

2.7 Microorganisms of milk

2. 2.7.1Bacteria

2.7.1.1. Coliform

2.7.2 Yeast and Moulds

2.8 Safe food handling

2.9 Shelf life and dating of food

2.10 Quality assurance

2.11 Cleaning of Dairy Equipment

3.0Material and Methods

3.1 Material

3.2 Method

3.2.1 Media preparation for microbiological test

3.2.1.1 Peptone dilution

3.2.1.2 Potato dextrose agar

3.2.1. 3. Tartaric acid

3.2.1.4 MacConkey broth(purple)

3.2.1.2 Milk agar

3.2.2 Chemical tests

3.2.2.1 Test for acidity

3.2.3 Microbiological testing procedures

3.2.3.1 Procedure for Yeast and Moulds

3.2.3.2 Total colony count 
$\begin{array}{ll}\text { 4.0 Result and discussion } & 34\end{array}$

$\begin{array}{ll}\text { 4.1. Initial yeast count } & 34\end{array}$

$\begin{array}{ll}\text { 4.2. Initial moulds count } & 34\end{array}$

4.3.1 Effect of Temperature on the growth of yeast 35

4.3.2 Effect of Temperature on the growth of Moulds 36

4.4 PH development of yoghurt with time at two different storage temperatures 36

$\begin{array}{ll}4.5 \text { Indication of coliforms } & 37\end{array}$

4.7 Investigation of yeast and mould 38

count in different points of production line

4.8 Investigation of Total bacterial colony count in

different points of production line

4.9 Investigation of presumptive coliforms in

different point of production process

4.10 Exposed plates to check the environment of the production section 41

$\begin{array}{ll}\text { 4.11 Personal hygienic condition } & 41\end{array}$

4.12 Effect of Mix storage temperature and time 42

4.13 Investigation of packing material 43

4.14 Investigation of Raw material $\quad 43$

4.15 Evaluation of yoghurt production process, the production environment after take the corrective actions 
4.15.1 Additional fumigation treatments in order to control yeast and moulds

4.16 Bacterial count variation after correct the critical points

4.17Investigation of the yeast and mould count in different points of production line in the new system

4.18 Investigation of the final product

4.19 Changes in PH with 2 storage temperatures

4.20 Changes of yeast count in two different temperatures

5.0 Conclusion

6.0 Reference

54 


\section{$\underline{\text { LIST OF TABLES }}$}

Table

Page

2.1. Composition of Milk 04

2.2.1 The concentration of proteins in milk: 05

2.2.3 The vitamin content of fresh milk 07

2.2.4. The mineral content of fresh milk 08

2.3 Energy value of individual milk constituent 10

2.4.3 Composition of plain yoghurt 14

2.5 Nutritional highlights of yoghurt 18

4.6 Relation ship with Yeast,Mould and coliforms with colour separation $\quad 38$

4.9 Investigation of presumptive coliforms in different points of production $\quad 40$ process

4.10 Indication of coliforms 40 


\section{LIST OF FIGURES}

Figure

Page

$\begin{array}{lll}2.1 & \text { Flow diagram of production process of yoghurt } & 14\end{array}$

4.1. Yeast count in several yoghurt batches 34

4.2. Mould count in several yoghurt batches 34

4.3.1 Effect of storage temperature for growth of yeast 35

4.3.2 Effect of storage temperature for growth of moulds 36

4.4. PH change under 2 different storage temperature with time 36

4.5: Percentage of coliform positive and negative samples 37

4.7: Changes of yeast and mould count in different points of production process 38

4.8 Totol bacterial count variation in different processing points 39

4.10 Yeast and mould colonies variation in different production points 41

4.11 Percentage of coliform positive and negative samples 41

4.12 Changes of Total colony count with time 42

4.13 Yeast and mould count in filling cups 43

4.14 Yeast and mould count in Raw material 43

4.15.1Changing of yeast count in different places in factory premises 45

4.15.2Changes of the moulds count in different places in factory premises $\quad 46$

4.16 Changes of the bacterial count in different points of the process 47

4.17 Changes of the yeast and mould count in different points of the process 48

4.18 Yeast count in different yoghurt batches 49

4.19 Changes of PH of the yoghurt with time, in two different storage temperatures $\quad 50$

4.20 Changes of yeast count in two different temperatures. 51 


\section{List of Abrevations}

$\begin{array}{lll}\text { 1. } & \text { T.C.C } & \text { Total Colony Count } \\ 2 & \text {.PDA } & \text { Potato Dextrose Agar } \\ 3 & \text {.PHE } & \text { Plate Heat Exchanger } \\ 4 & \text { HTST } & \text { High Temperature Short Time } \\ 5 . & \text { SNF } & \text { Solids Not Fat }\end{array}$


INCIDENCE OF COLIFORM,YEAST AND MOULDS IN

YOGHURT AND ITS RELATIONSHIP TO SHORTENING OF SHELF LIFE

BY

\section{BUDAGODA ARACHCHIGE DONA RASIKA \\ SANDEEPANI WIJEWARDENA}

\section{ABSTRACT}

Milk is a highly perishable commodity because of its high nutritive value and it's liquid state provides an ideal medium for the growth of spoilage micro organisms. The hot climate in Sri Lanka too increases the spoilage. So the processing of fresh milk into more stable forms has to be done as fast as possible with maximum preservation of the nutrient originally present.

Yoghurt is one of the products which is very famous not only in Sri Lanka but all around the world. In Sri Lanka, Milco (Pvt) Limited is one of the leading companies which supplies more than $50 \%$ of the yoghurt demand in the market. This study was carried out at Milco (Pvt) Ltd ,No 45 Nawala Road ,Narahenpita, Colombo 05.

This research was carried out to find out the incidence of coliform, yeast, and moulds in yoghurt and it's relationship to shortening of shelf life of the product.

The shelf life of yoghurt is 15 days after the production date. Without adding any preservatives the shelf life can be further increased if the product is produced without any micro organism contamination 
In this system, coliform contamination mainly occur due to unhygienic practices of the workers and due to lapses in the sanitization practices. Sanitization procedures of the production process should be properly followed and monitored to minimize the bacterial contamination

Yeast and moulds contamination taken place mainly due to environmental lapses. More than Moulds, Yeast is the most common spoilage found in yoghurt. There is no relationship with Yeast and Moulds count with colour separation. When Yeast count increases yoghurt bloats. The indication of the presence of coliform has no relationship to the colour separation. Initial bacterial count is very high in raw milk $>30000 \mathrm{cfu} / \mathrm{ml}$.

By using proper pasteurization time, temperature combinations for raw milk ( $76^{\circ} \mathrm{c}-14$ seconds) and for yoghurt mix pasteurisations $\left(95^{\circ} \mathrm{C}-5 \mathrm{Min}\right)$ the microbial count can be reduced. Also the storage temperature is very critical, for the growth of Microganism. By maintaining the cold chain $\left(<5^{\circ} \mathrm{C}\right)$ through out the production process the microbial spoilage can be minimized. 


\section{Introduction}

Milk is secreted by mammals for the nourishment of their young and the milk of all species are complex biological fluids containing a wide variety of different constituents and possessing unique physical characteristics.

The major constituent of cow's milk is water the remainder consists largely of lipids, proteins and carbohydrates, vitamins and minerals also present in smaller quantities. Milk is also regarded as being nature's most complete food, because it provides many of the nutrients which are essential for the growth of the human body .However the high moisture content, abundant supply of nutrients together with the almost neutral acidity and temperature of raw milk make it particularly prone to spoilage by micro organisms either originally present or introduced during handling Therefore, necessary steps must be taken to extend the shelf life of raw milk The forms in which milk is processed range from liquid like pasteurized milk, sterilized milk and to products like yoghurt, butter, cheese ,ice cream etc .

Yoghurt (also spelled yogourt or yoghurt) is a semi-solid fermented milk product which originated centuries ago in Bulgaria. It's popularity has grown and is now consumed in most parts of the world. Although the consistency, flavour and aroma may vary from one region to another, the basic ingredients and manufacturing are essentially consistent. Two types of bacteria are involved in fermentation of yoghurt.

Streptococcus thermophilus ./Lactobacillus bulgaricus.

Streptococcus thermophilus. is responsible for the pleasant aroma present in the yoghurt.L.bulgaricus sets the yoghurt by developing an acidic condition in the conversion of lactose in milk to lactic acid. 
The milk industries of Lanka Co Limited (MILCO) plays a major role in milk collection and processing in Sri Lanka.It owns 3 processing plants located in Ambewella,Colombo and Kandy.The products of Milco Pasteurised milk,Sterized milk, Powdered milk yoghurt, Ice cream and cheese. In Sri lanka Milco company (successors to National Milk Board) is one of the leading companies involved in yoghurt production. The company started yoghurt manufacturing in 1970's.Current average production of yoghurt/day ranges about 150000 cups per day.

Presently MILCO company is involved in the production of set yoghurt, flavoured yoghurt and stirred type drinking yoghurt. However there are many problems regarding the shelf life of yoghurt. Recently the company approves 15 days of shelf life for their set yoghurts. There are many reasons which result in a short shelf life. They are, Acidity development, Bloting, colour separation of yoghurt . Yeast, mould and coliform and the initial bacterial count affect the yoghurt shelf life.Therefore studying the incidence of coliform, yeast and mould in yoghurt is important, and also it is important to find out the relationship to shorning the shelf life. The expansion of shelf life of yoghurt is important to fulfil the high demand,minimize wastage,reduce transport costs and finally to increase the productivity and profitability in yoghurt manufacturing. This project was carried out to investigate the incident of coliform, yeast and mould contamination in yoghurt and it s relation ship to shortning the shelf life of the product.This was in order to develop procedures to evaluate the keeping quality or shelf life of yoghurt. 